DE LEGA LATA

Jurnal Ilmu Hukum

FAKULTAS HUKUM UMSU
Perlindungan Hukum Terhadap...(Tria Agustia, dkk)

Volume 5 Nomor 1, Januari - Juni 2020, 106-114

DOI: https://doi.org/10.30596/dll.v5i1.3493

\title{
PERLINDUNGAN HUKUM TERHADAP KREDITUR DALAM PEMBEBANAN HAK TANGGUNGAN OBJEK YANG BELUM TERDAFTAR
}

\author{
Tria Agustia,Yulia Mirwati, Busyra Azheri \\ Magister Kenotariatan, Universitas Andalas, Jalan Pancasila Nomor 10, \\ Kota Padang, Provinsi Sumatera Barat, Indonesia \\ Email: qinarahma21@gmail.com, yuliamirwati@gmail.com, \\ busyra@law.unand.ac.id,
}

\begin{abstract}
Abstrak
Penelitian ini dilakukan di daerah Kabupaten Tulang Bawang Provinsi Lampung, dimana ditemukan masih sangat banyak masyarakat yang hanya memiliki Surat Keterangan Tanah (SKT) atau Surat Pernyataan Pemilikan dan Penguasaan Fisik Bidang Tanah (Sporadik) sebagai bukti kepemilikan tanah dan mereka ingin mendapatkan fasilitas kredit dengan menjaminkan Surat Keterangan Tanah (SKT) atau Surat Pernyataan Pemilikan dan Penguasaan Fisik Bidang Tanah (Sporadik) tersebut. Pokok permasalahan yang dikaji adalah perlindungan hukum dalam pembebanan hak tanggungan objek yang belum terdaftar yang dijadikan jaminan. Jenis penelitian adalah penelitian empiris. Hasil penelitian menunjukan bahwa perlindungan hukum terhadap kreditur dalam pembebanan hak tanggungan terhadap objek yang belum terdaftar adalah berpegang pada perjanjian kredit yang berkedudukan sebagai perjanjian pokok yang mengikat para pihak yang membuatnya dan pada akta kuasa menjual barang jaminan yang ditandatangani pada saat penandatangan perjanjian kredit.
\end{abstract}

\section{Kata Kunci: Perlindungan Hukum Kreditur, Hak Tanggungan, Kepemilikan.}

\section{Abstract}

This research was conducted in the area of Tulang Bawang Regency, Lampung Province, where it was found that there were still very many people who only had a Land Certificate (SKT) or a Statement of Physical Ownership and Control of a Land Sector (Sporadic) as proof of land ownership and they wanted to get credit facilities by guaranteeing Land Certificate (SKT) or Statement of Ownership and Physical Control of the Land Sector (Sporadic). The subject matter examined is the legal protection in the imposition of mortgage rights of objects that have not been registered as collateral. This type of research is empirical research. The results showed that the legal protection of creditors in the imposition of mortgage rights for objects that have not been registered is holding on a credit agreement that is domiciled as the principal agreement that binds the parties that made it and on the power of attorney to sell the collateral that was signed when signing the credit agreement.

Keywords: Legal Protection of Creditors, Morgatge Right, Ownership.

\section{PENDAHULUAN}

Pembangunan nasional di bidang ekonomi dan dunia usaha memerlukan dukungan modal yang cukup besar. Modal tersebut dapat diperoleh dari berbagai sumber, yang salah satunya adalah berasal dari fasilitas pinjaman atau kredit yang diberikan oleh bank. Bank adalah badan usaha yang menghimpun dana dari masyarakat dalam bentuk simpanan dan menyalurkan kepada masyarakat dalam bentuk kredit dan atau bentuk-bentuk lainnya dalam rangka meningkatkan taraf hidup rakyat banyak (Zainal Asikin, 2015: h. 28). 
DE LEGA LATA

Jurnal Ilmu Hukum

FAKULTAS HUKUM UMSU
Perlindungan Hukum Terhadap...(Tria Agustia, dkk)

Volume 5 Nomor 1, Januari - Juni 2020, 106-114 DOI: https://doi.org/10.30596/dll.v5i1.3493

Bank yang dapat menyalurkan kredit tidak hanya Bank Umum saja, melainkan juga Bank Perkreditan Rakyat (BPR). Hal ini sejalan dengan pendapat Hermansyah, yang menyatakan sebagai berikut, Usaha BPR hanya meliputi :

a. Menghimpun dana dari masyarakat dalam bentuk simpanan berupa deposito berjangka, tabungan, dan/atau bentuk kegiatan yang dipersamakan dengan itu.

b. Memberikan kredit

c. Menyediakan pembiayaan dan kesempatan dana berdasarkan Prinsip Syariah sesuai ketentuan yang ditetapkan oleh Bank Indonesia.

d. Menempatkan dananya dalam bentuk Sertipikat Bank Indonesia (SBI), deposito berjangka, sertipikat deposito dan/atau tabungan pada bank lain (Hermansyah, 2013: h. 24)

Setiap proses pemberian kredit oleh bank harus didahului dengan penelitian dan analisis yang mendalam dari berbagai aspek, baik aspek ekonomi maupun aspek hukum. Ketentuan Pasal 8 dan Pasal 15 Undang-Undang Nomor 10 Tahun 1998 tentang Perbankan menegaskan bahwa dalam pemberian kredit bank wajib mempunyai keyakinan berdasarkan analisis yang mendalam atas itikad dan kemampuan serta kesanggupan nasabah debitur untuk melunasi utangnya sesuai dengan yang diperjanjikan. Dengan demikian diperlukan analisis yang mendalam sebelum bank memutuskan menyetujui permohonan kredit dari si debitur. Sesuai dengan penjelasan Pasal 8 UU Perbankan maka analisis tersebut mencakup penilaianpenilaian terhadap 5C (the five C's prinsiples), yaitu: Character (kejujuran atau itikat baik), Capacity (kemampuan); Capital (modal); Condition of Economic (kondisi ekonomi); Collateral (agunan dan jaminan) (Muhammad Djumhana, 1997: h. 394).

Pemberian kredit oleh bank selaku Kreditur kepada Debitur diawali dengan perjanjian kredit, yang pada intinya merupakan proses pemberian "jaminan atau agunan" dari pihak Debitur sebagai peminjam dana. Agunan adalah sesuatu yang diberikan kepada Kreditur untuk menimbulkan keyakinan bahwa Debitur akan memenuhi kewajiban yang timbul dari suatu perikatan (Hermansyah, 2013: h. 24). Atau bUndang-Undangdisebut juga jaminan atau agunan merupakan barang bergerak ataupun yang tidak bergerak yang diserahkan oleh debitur untuk menjamin ketepatan dan pembayaran kembali kredit yang diberikan oleh Bank kepada Debitur, yang suatu saat dapat dipergunakan oleh Bank sebagai sumber pelunasan pembayaran kembali pinjaman debitur apabila karena suatu hal debitur tidak dapat melaksanakan pembayaran kembali pinjaman kepada Bank dengan baik. Salah satu benda yang sering dijadikan agunan adalah tanah, karena tanah memiliki nilai ekonomi yang tinggi dibandingkan dengan kendaraan bermotor.

Tanah-tanah yang dapat dibebani dengan hak tanggungan ada yang telah bersertipikat namun ada pula yang belum bersertipikat. Sertipikat merupakan surat tanda bukti hak, yang dikeluarkan oleh Kantor Pertanahan sesuai ketentuan Peraturan Pemerintah Nomor 24 Tahun 1997 tentang Pendaftaran Tanah, (Lembaran Negara Republik Indonesia Tahun 1960, Tambahan Lembaran Negara Republik Indonesia Nomor 203) untuk selanjutnya ditulis PP 24/1997. Sedangkan hak atas tanah yang belum bersertipikat merupakan tanah yang belum terdaftar pada Kantor Pertanahan setempat. Dalam Pasal 10 ayat (3) Undang-Undang Nomor 4 tahun 1996 tentang Hak Tanggungan menyatakan bahwa apabila obyek hak tanggungan berupa 


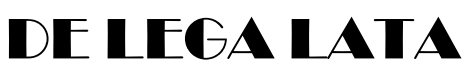

Jurnal Ilmu Hukum

FAKULTAS HUKUM UMSU
Perlindungan Hukum Terhadap...(Tria Agustia, dkk)

Volume 5 Nomor 1, Januari - Juni 2020, 106-114 DOI: https://doi.org/10.30596/dll.v5i1.3493

hak atas tanah yang berasal dari konversi hak lama yang telah memenuhi syarat untuk didaftarkan akan tetapi pendaftarannya belum dilakukan, pemberian hak tanggungan dilakukan bersamaan dengan permohonan pendaftaran hak atas tanah yang bersangkutan.

Jadi pada saat penandatanganan perjanjian kredit diserahkan juga dokumen-dokumen keperluan pendaftaran tanah untuk pertama kalinya sehingga setelah sertipikat hak atas tanah terbit bisa langsung diproses pendaftaran pembebanan hak tanggungannya oleh Pejabat Pembuat Akta Tanah (PPAT).

Walaupun dalam Undang-Undang Hak Tanggungan Atas Tanah Beserta Benda-Benda yang Berkaitan dengan Tanah dan dalam SK Direksi Bank Indonesia Nomor 23/69/KEP/DIR/1991 Tentang Jaminan Pemberian Kredit menyebutkan bahwa tanah-tanah yang belum terdaftar tidak dilarang untuk dijadikan sebagai jaminan atau agunan pada perbankan namun pada kenyataannya tidak semua bank mau menerima jaminan tanah yang belum terdaftar ini. Banyak bank yang menolak jaminan terhadap objek tanah yang belum terdaftar dengan alasan untuk keamanan bank. Bank tersebut takut jika mereka menerima jaminan berupa objek tanah yang belum terdaftar dan dalam rentang waktu pengurusan sertipikat atas objek tanah yang belum terdaftar tersebut memakan waktu yang cukup lama, dan debitur melakukan suatu wanprestasi maka pihak Bank atau lembaga pembiayaan tidak memiliki pegangan yang kuat untuk dapat mengeksekusi barang jaminan yaitu objek tanah yang belum terdaftar tersebut. Ini disebabkan karena proses pemasangan Akta Pembebanan Hak Tanggungan (APHT) belum terlaksana disebabkan tanah masih dalam proses pendaftaran. Dan hal ini tentunya berpotensi merugikan pihak Bank sebagai kreditur.

Sebagian besar masyarakat di Kabupaten Tulang Bawang Provinsi Lampung masih banyak yang belum mendaftarkan tanah-tanah yang dimilikinya. Sebagian besar adalah masyarakat yang ada di pedalaman yang akses jalannya tidak bagus dan membutuhkan waktu yang lama jika ingin ke pusat kota dimana pusat pemerintahan berjalan. Pada umumnya masyarakat disana hanya memiliki Surat Keterangan Tanah (SKT) atau Surat Pernyataan Pemilikan dan Penguasaan Fisik Bidang Tanah (Sporadik) saja.

Walaupun mereka hanya memiliki Surat Keterangan Tanah (SKT) atau Surat Pernyataan Pemilikan dan Penguasaan Fisik Bidang Tanah (Sporadik) mereka juga bisa mendapatkan fasilitas kredit karena disalah satu BPR di Kabupaten Tulang Bawang dapat menerimanya sebagai jaminan kredit. Seperti contoh kasus Debitur dengan inisial ST pada salah satu BPR di Kabupaten Tulang Bawang yang menjaminkan Surat Keterangan Tanah (SKT) atau Surat Pernyataan Pemilikan dan Penguasaan Fisik Bidang Tanah (Sporadik) untuk mendapatkan fasilitas kredit dan dalam perjalanan masa kredit tersebut 2 (dua) bulan menjelang jangka waktu kredit habis Debitur tersebut menunggak pembayaran dan ketika kredit jatuh tempo Debitur menolak melunasi utangnya dengan alasan sertipikat atas tanahnya belum selesai didaftarkan, karena ternyata proses pendaftaran pertama kali untuk sertipikat hak memerlukan waktu yang cukup lama. Dari kasus tersebut maka perlindungan hukum harus diberikan kepada kreditur yang jaminan kreditnya atas tanah yang belum terdaftar karena pada saat rentang waktu proses penerbitan sertipikat itu debitur wanprestasi hak-hak kreditur dapat terlindungi dan supaya apabila nantinya terbit sertipikat dapat segera dipasang Akta Pemberian Hak 
DEIEGA LATA

Jurnal Ilmu Hukum

FAKULTAS HUKUM UMSU
Perlindungan Hukum Terhadap...(Tria Agustia, dkk)

Volume 5 Nomor 1, Januari - Juni 2020, 106-114 DOI: https://doi.org/10.30596/dll.v5i1.3493

Tanggungan (APHT) dan diterbitkan Sertipikat Hak Tanggungan (SHT), sehingga kedudukan kreditur dapat sebagai kreditur preferent.

Berdasarkan uraian di atas yang menjadi pokok permasalahan yang akan dibahas yaitu perlindungan hukum terhadap kreditur dalam pembebanan objek Hak Tanggungan belum terdaftar yang dijadikan jaminan.

\section{METODE PENELITIAN}

Metode pendekatan yang digunakan dalam penelitian ini, adalah penelitian empiris yaitu pendekatan terhadap masalah yang ada dengan jalan memahami atau mempelajari hukum positif dari suatu objek penelitian dan bagaimana kenyataan atau prakteknya dilapangan. Penulis mewawancarai pihak-pihak yang terkait dengan objek penelitian Penulis, diantaranya yaitu: pegawai bank dan Notaris/PPAT rekanan Bank yang berada di Kabupaten Tulang Bawang. Analisis data dilakukan dengan data yang dianalisis secara kualitatif, (Soerjono Soekanto, 2008: h. 250) yaitu data sekunder yang berupa teori, definisi dan substansinya dari berbagai literatur, dan peraturan perundang-undangan, serta data primer yang diperoleh dari wawancara, kemudian dianalisis dengan teori dan pendapat pakar yang relevan, sehingga didapat kesimpulan.

\section{PEMBAHASAN DAN ANALISIS}

\section{Konsep Jaminan}

Istilah jaminan berasal dari terjemahan bahasa Belanda yaitu "zeherheid". Zeherheid mencakup bagaimana cara kreditur menjamin dipenuhinya tagihannya disamping penanggungan jawab umum debitur terhadap barang-barangnya (Salim HS, 2004, h. 21). M. Bahsan mendefinisikan jaminan adalah segala sesuatu yang diterima kreditur dan diserahkan debitur untuk menjamin suatu piutang dalam masyarakat. (Muhammad Bahsa, 2002, h. 148).

Jaminan merupakan sesuatu yang diberikan kepada kreditur untuk menimbulkan keyakinan bahwa debitur akan memenuhi kewajiban yang dapat dinilai dengan uang yang timbul dari suatu perikatan. Dalam praktek perbankan terdapat dua istilah yang dipergunakan untuk menjelaskan adalah jaminan yaitu jaminan dan agunan. Jaminan dimaksud sebagai kepercayaan yang diberikan oleh kreditur bank atas itikad baik dan kemampuan membayar utang atau kewajiban debitur, sedangkan agunan dimaksudkan dengan barang-barang kebendaan milik debitur yang dijadikan jaminan untuk melunasi utangny (Surhaningsih, 2011, h. 19). Jaminan kebendaan dibagi menjadi 2 (dua), yaitu jaminan kebendaan untuk benda tidak bergerak dan jaminan kebendaan bergerak. Pembedaan benda bergerak dan tidak bergerak ini penting untuk penguasaan (bezit), penyerahan (levering), pembebanan (bezwaring) dan kadaluarsa (verjaring) (Rachmadi Usman, 2008: h. 48).

Untuk jaminan benda tidak bergerak yaitu tanah, maka lembaga jaminannya adalah hak tanggungan dan tunduk pada Undang-Undang Hak Tanggungan. Jaminan kebendaan benda bergerak tunduk pada lembaga jaminan fidusia dan gadai. Jaminan fidusia diatur dalam Undang-undang Jaminan Fidusia, sedangkan lembaga jaminan gadai diatur dalam Pasal 1150 KUH Perdata yang mengatur tentang gadai. 


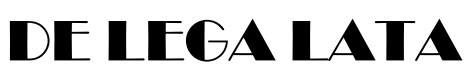

Jurnal Ilmu Hukum

FAKULTAS HUKUM UMSU
Perlindungan Hukum Terhadap...(Tria Agustia, dkk)

Volume 5 Nomor 1, Januari - Juni 2020, 106-114 DOI: https://doi.org/10.30596/dll.v5i1.3493

\section{Definisi Hak Tanggungan}

Berdasarkan Pasal 1 angka 1 Undang-Undang Hak Tanggungan merumuskan definisi Hak Tanggungan. Definisi hak tanggungan tersebut adalah sebagaimana berikut:

Hak Tanggungan atas tanah beserta benda-benda yang berkaitan dengan tanah, yang selanjutnya disebut Hak Tanggungan, adalah hak jaminan yang dibebankan pada hak atas tanah sebagaimana dimaksud dalam Undang-Undang Nomor 5 Tahun 1960 tentang Peraturan Dasar Pokok-Pokok Agraria, berikut atau tidak berikut benda benda lain yang merupakan satu kesatuan dengan tanah itu, untuk pelunasan utang tertentu, yang memberikan kedudukan yang diutamakan kepada kreditor tertentu terhadap krediturkreditur lain.

Boedi Harsono mendefinisikan hak tanggungan sebagai penguasaan hak atas tanah, berisi kewenangan bagi kreditur untuk berbuat sesuatu mengenai tanah yang dijadikan agunan, tetapi bukan untuk dikuasai secara fisik dan digunakan, melainkan untuk menjualnya jika debitur cedera janji dan mengambil dari hasilnya seluruhnya atau sebagian sebagai pembayaran lunas debitur kepadanya (Salim HS, 2004, hal. 97). Hak tanggungan merupakan perjanjian accesoir artinya disampingnya ada perjanjian pokok yang berwujud perjanjian pinjam-meminjam uang. Sifat hak tanggungan yang merupakan perjanjian assesoir maka adanya tergantung pada perjanjian pokok, dan akan hapus dengan hapusnya perjanjian pokok (Titik Triwulan Tutik, 2008, h. 182).

\section{Perlindungan Hukum Terhadap Kreditur Dalam Pembebanan Objek Hak Tanggungan Belum Terdaftar yang Dijadikan Jaminan}

Perlindungan hukum merupakan bentuk bekerjanya fungsi hukum untuk mewujudkan tujuan hukum, yaitu keadilan, kemanfaatan dan kepastian hukum. Satjipto Raharjo mendefinisikan perlindungan hukum adalah memberikan pengayoman kepada hak-hak asasi manusia yang dirugikan oleh orang lain dan perlindungan tersebut diberikan kepada masyarakat agar mereka dapat menikmati semua hak-hak yang diberikan oleh hukum (Satjipto Rahardjo, 1993. h. 34).

Sengketa yang terjadi di masyarakat harus diselesaikan berdasarkan hukum yang berlaku untuk mencegah tindakan main hakim sendiri oleh masyarakat. Hukum memiliki fungsi untuk mengatur hubungan antara negara dengan masyarakat dan hubungan antara masyarakat dengan sesama masyarakat, agar terciptanya kehidupan masyarakat yang tertib. Hal tersebut menuntut hukum agar menciptakan suatu kepastian hukum dan keadilan dalam kehidupan masyarakat.

Kepastian hukum mengharuskan terciptanya suasana yang aman dan tentram dalam masyarakat, maka kaidah dimaksud harus ditegakkan serta dilaksanakan dengan tegas. Dengan adanya suatu kepastian hukum maka akan tercipta suatu perlindungan hukum bagi masyarakat, karena masyarakat telah mendapatkan kepastian hukum tentang bagaimana masyarakat menyelesaikan suatu persoalan hukum yang mereka hadapi.

Dari kasus Debitur ST penyelesaian pendaftaran sertipikat hak miliknya baru selesai pada tanggal 02 Juni 2016 dari awal tanggal fasilitas kreditnya tanggal 22 September 2014 hampir memakan waktu 2 (dua) tahun baru sertipikat hak milik Bapak ST tersebut selesai. Dan ini sungguh sangat membuat baik pihak Bank maupun Notaris/PPAT sedikit kerepotan karena jangka waktu fasilitas kredit Debitur ST yang hanya 1 (satu) tahun yang berarti ketika pada tanggal 22 September 2015 kredit Debitur ST jatuh tempo untuk dilunasi sedangkan sertipikat 


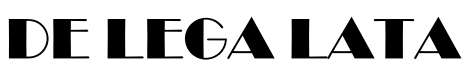

Jurnal Ilmu Hukum

FAKULTAS HUKUM UMSU
Perlindungan Hukum Terhadap...(Tria Agustia, dkk)

Volume 5 Nomor 1, Januari - Juni 2020, 106-114 DOI: https://doi.org/10.30596/dll.v5i1.3493

hak miliknya belum juga selesai padahal dia telah membayar cukup mahal untuk itu secara lunas, hal ini menimbulkan sedikit kekecewaan pada Debitur ST sehingga ia menolak untuk melunasi hutangnya dan meminta perpanjangan waktu kreditnya. Dan hal inipun membuat pihak Bank sedikit dilema karena pada saat jatuh tempo tersebut posisi kredit Debitur ST menunggak cicilan bunga selama 2 (dua) bulan menurut si Debitur ini disebabkan karena produksi sawit dan harga sawit turun dratis dipasaran sehingga sedikit mengganggu pemasukan usaha Debitur itu sendiri.

Eksistensi hukum di dalam masyarakat pada dasarnya berfungsi untuk melindungi kepentingan manusia (Munir Fuady, 2013: h. 8). Tanah yang telah terdaftar dan memiliki sertipikat lembaga jaminannya adalah Hak Tanggungan, sedangkan tanah yang belum terdaftar sampai saat ini belum ada lembaga jaminannya. Berdasarkan wawancara dengan Direktur salah satu BPR di Kabupaten Tulang Bawang, Akta Pemberian Hak Tanggungan (APHT) yang belum dapat didaftarkan karena proses penerbitan sertipikat hak atas tanahnya yang belum selesai tidak akan menimbulkan persoalan apabila Debitur tidak melakukan wanprestasi. Baru akan menjadi masalah apabila Debitur wanprestasi karena Akta Pemberian Hak Tanggungan (APHT) yang belum dapat didaftarkan sehingga tidak memiliki kekuatan eksekutorial (Data wawancara Herman, Direktur BPR Kabupaten Tulang Bawang, Tanggal 24 April 2019). Aspek yang paling penting dari sifat hak tanggungan bagi Kreditur kredit perbankan adalah memberikan kedudukan yang diutamakan kepada Kreditur pemegang hak tanggungan sebagaimana ketentuan Pasal 1 angka 1 Undang-Undang Nomor 4 Tahun 1996 tentang Hak Tanggungan Atas Tanah Beserta Benda-Benda yang Berkaitan dengan Tanah. Kemudian Pasal 20 ayat (1) Undang-Undang Nomor 4 Tahun 1996 tentang Hak Tanggungan Atas Tanah Beserta Benda-Benda yang Berkaitan dengan Tanah menentukan bahwa apabila Debitur cidera janji maka Kreditur pemegang hak tanggungan berhak untuk menjual obyek yang dijadikan jaminan melalui pelelangan umum menurut peraturan yang berlaku dan mengambil pelunasan piutangnya dari hasil penjualan tersebut, dengan hak mendahului dari pada Kreditur lain yang bukan pemegang hak tanggungan atau Kreditur pemegang hak tanggungan dengan peringkat yang lebih rendah. Hak istimewa ini tentu saja tidak dipunyai oleh Kreditur bukan pemegang hak tanggungan.

Akibat hukum dari belum dapat didaftarkannya Akta Pemberian Hak Tanggungan ( APHT) terhadap perjanjian kredit perbankan yang dibuat oleh Kreditur dan Debitur tersebut adalah perjanjian kredit tersebut tetap sah sepanjang memenuhi ketentuan Pasal $1320 \mathrm{KUH}$ Perdata. Perjanjian kredit perbankan yang dibuat tersebut berkedudukan sebagai perjanjian pokok yang mengikat para pihak yang membuatnya. Disini berlaku asas pacta sunt servada, perjanjian tersebut menjadi undang-undang bagi pihak yang membuatnya.

Mengenai perjanjian kredit dengan jaminan Hak Tanggungan, pada umumnya juga mengacu pada Undang-Undang Nomor 4 Tahun 1996 tentang Hak Tanggungan Atas Tanah Beserta Benda-Benda yang Berkaitan dengan Tanah. Undang-Undang ini menyebutkan bahwa perjanjian jaminan Hak Tanggungan mengikuti perjanjian dasar atau perjanjian pokoknya terhadap berikut atau tidak berikut benda-benda lain yang merupakan satu kesatuan dengan tanah itu, untuk pelunasan utang tertentu, yang memberikan kedudukan yang diutamakan kepada kreditur tertentu terhadap kreditur-kreditur lain. Sehingga, bila debitur lalai membayar 


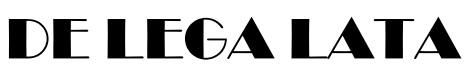

Jurnal Ilmu Hukum

FAKULTAS HUKUM UMSU
Perlindungan Hukum Terhadap...(Tria Agustia, dkk)

Volume 5 Nomor 1, Januari - Juni 2020, 106-114 DOI: https://doi.org/10.30596/dll.v5i1.3493

hutangnya, bank sebagai kreditur pemegang Hak Tanggungan mempunyai hak untuk menjual jaminan dan lebih diutamakan untuk mendapatkan pelunasan hutang dari penjualan jaminan tersebut.

Berdasarkan Pasal 20 ayat (1) b Undang-Undang Nomor 4 Tahun 1996 tentang Hak Tanggungan Atas Tanah Beserta Benda-Benda yang Berkaitan dengan Tanah dapat dipahami, bahwa apabila debitur cidera janji, maka Titel Eksekutorial pada Sertipikat Hak Tanggungan yakni "DEMI KEADILAN YANG BERDASARKAN KETUHANAN YANG MAHA ESA" menjadi alas hak bagi bank untuk melakukan penjualan barang tidak bergerak milik debitur yang menjadi objek Hak Tanggungan di muka umum dengan bantuan pejabat lelang dan hasil penjualan ini diambil bank sebagai pelunasan utang debitur, sedangkan Akta Pemberian Hak Tanggungan (APHT) yang belum dapat didaftarkan karena proses penerbitan sertipikatnya yang belum selesai, konsekuensinya tidak memenuhi asas publisitas dan asas preferensi, sesuai dengan ketentuan Pasal 13 Undang-Undang Nomor 4 Tahun 1996 tentang Hak Tanggungan Atas Tanah Beserta Benda-Benda yang Berkaitan dengan Tanah. Perlindungan hukum bagi Kreditur dalam hal Akta Pemberian Hak Tanggungan (APHT) yang belum bisa didaftarkan sebenarnya sangatlah lemah.

Bank hanya dapat mengupayakan penyelesaian secara musyawarah jika terjadi kredit macet dan berharap si debitur akan beritikad baik dengan sukarela menyerahkan jaminannya untuk dieksekusi oleh pihak Bank. Akan tetapi Bank juga dapat melakukan antisipasi dengan menandatangani akta kuasa untuk menjual atas benda jaminan dari Debitur kepada Kreditur dihadapan Notaris/PPAT. Sehingga jika Debitur melakukan wanprestasi sebelum sertipikat hak tanggunngannya terbit maka Kreditur memiliki pegangan yang cukup kuat untuk dapat melelang barang jaminan dari pihak Debitur yang melakukan wanprestasi tersebut. Jadi perlindungan hukum preventif yang dapat dilakukan oleh kreditur dalam hal Akta Pemberian Hak Tanggungan (APHT) belum dapat didaftarkan karena objek jaminan yang belum selesai proses pendaftarannya adalah dengan membuat akta kuasa jual atas benda jaminan dari Debitur kepada Kreditur dan lebih baik dalam bentuk akta otentik agar pembuktiannya lebih sempurna dan kuat, sedangkan perlindungan hukum represifnya setelah Sertipikat Hak Tanggungan (SHT) terbit sehingga menjadikan kedudukan kreditur sebagai kreditur preferent sehingga dengan Titel Eksekutorial pada Sertipikat Hak Tanggungan (SHT) kreditur dapat menjual barang jaminan Debitur jika Debitur tersebut terbukti wanprestasi.

\section{KESIMPULAN}

Perlindungan hukum terhadap kreditur dalam pembebanan hak tanggungan terhadap objek yang belum terdaftar adalah berpegang pada perjanjian kredit yang telah ditandatangani oleh kedua belah pihak yang berkedudukan sebagai perjanjian pokok yang mengikat para pihak yang membuatnya dan berlaku sebagai undang-undang bagi para pihak tersebut. Perlindungan hukum bagi Kreditur dalam hal Akta Pemberian Hak Tanggungan (APHT) yang belum bisa didaftarkan dapat dilakukan dengan menandatangani akta kuasa untuk menjual atas benda jaminan dari Debitur kepada Kreditur dengan akta yang dibuat oleh dan dihadapan Notaris/PPAT. Sehingga jika Debitur melakukan wanprestasi sebelum sertipikat hak tanggunngannya terbit maka Kreditur memiliki pegangan yang cukup kuat untuk dapat 
DEIEGA LATA

Jurnal Ilmu Hukum

FAKULTAS HUKUM UMSU
Perlindungan Hukum Terhadap...(Tria Agustia, dkk)

Volume 5 Nomor 1, Januari - Juni 2020, 106-114

DOI: https://doi.org/10.30596/dll.v5i1.3493

melelang barang jaminan dari pihak Debitur yang melakukan wanprestasi tersebut dengan alat pembuktiannya akta otentikl dari Notari/PPAT yang telah dibuat tersebut.

\section{SARAN}

Hendaknya kreditur agar mendapatkan kekuatan hukum dan perlindungan hukum dalam mengeksekusi jaminan terhadap jaminan objek yang belum terdaftar jika si debitur wanprestasi, maka pemberian Surat Kuasa Membebankan Hak Tanggungan (SKMHT) harus segera dilanjutkan dengan Akta Pemberian Hak Tanggungan (APHT) untuk selanjutnya diterbitkan Sertipikat Hak Tanggungan(SHT) sehingga kreditur dapat digolongkan sebagai kreditur preferen dan dapat mengeksekusi jaminan debitur sebagai pengembalian utang kredit oleh Debitur yang wanprestasi. 
Jurnal Ilmu Hukum FAKULTAS HUKUM UMSU
Perlindungan Hukum Terhadap...(Tria Agustia, dkk)

Volume 5 Nomor 1, Januari - Juni 2020, 106-114 DOI: https://doi.org/10.30596/dll.v5i1.3493

\section{DAFTAR PUSTAKA}

Arba, HM. (2015). Hukum Agraria Nasional. Jakarta: Sinar Grafika

Asikin, Zainal. (2015). Pengantar Hukum Perbankan Indonesia. Jakarta: PT Raja Grafindo Persada

Djumhana, Muhammad. (1997). Hukum Perbankan Indonesia. Bandung: Citra Aditya Bakti,

Fuady, Munir. (2013). Hukum Jaminan Hutang. Jakarta: Erlangga

Hermansyah. (2013). Hukum Perbankan Nasional Indonesia. Jakarta: Kencana

Indri Hadisiswati (2014), Kepastian Hukum dan Perlindungan Hukum Hak atas Tanah, AHKAM, Volume 2, Nomor 1, 01 Juli 2014.

Kitab Undang-Undang Hukum Perdata (KUH Per).

Peraturan Menteri Negara Agraria/Kepala BPN Nomor 22 Tahun 2017 Tentang Penetapan Batas Waktu Penggunaan Surat Kuasa Membebankan Hak Tanggungan Untuk Menjamin Pelunasan Kredit Tertentu.

Peraturan Menteri Negara Agraria/Kepala BPN Nomor 3 Tahun 1997 Tentang Ketentuan Pelaksanaan Peraturan Pemerintah Nomor 24 Tahun 1997 Tentang Pendaftaran Tanah.

Peraturan Pemerintah Nomor 24 Tahun 1997 Tentang Pendaftaran Tanah.

Satjipto Rahardjo (1993), Penyelenggaraan Keadilan Dalam Masyarakat Yang Sedang Berubah, Jurnal Masalah Hukum, (selanjutnya disebut Satcipto Raharjo II)

Simun Ismaya. (2011). Pengantar Hukum Agraria. Yogyakarta: Graha Ilmu

SK Direksi Bank Indonesia Nomor 23/69/KEP/DIR/ 1991 Tentang Jaminan

Soerjono Soekanto (2008), Pengantar Penelitian Hukum, UI Press, Jakarta

Sri Handayani. (2015). Pendaftaran Hak AtasTanah Asal Leter C, Girik dan Petuk D Sebagai Alat Bukti Permulaan Di Kabupaten Sleman Daerah Istimewa Yogyakarta.” Jurnal Repertorium. Surakarta: UNS Pers. Edisi 2. Juli-Desember. Tahun II.

Undang-Undang Nomor 10 Tahun 1998 tentang Perubahan Undang-Undang Nomor 7 Tahun 1992 tentang Perbankan

Undang-Undang Nomor 4 Tahun 1996 tentang Hak Tanggungan Atas Tanah Beserta BendaBenda yang Berkaitan dengan Tanah.

Undang-Undang Nomor 5 Tahun 1960 tentang Pokok-pokok Agraria. 